\title{
STRATEGIES TO IMPROVE SPEAKING SKILL FOR TOURISM STUDENTS
}

\author{
Dhea Saragih $^{1}$, Olina Putri Batubara ${ }^{2}$, Vanessa Pritin Angel Halawa ${ }^{3}$, Sabarni \\ Rodearni Sipayung ${ }^{4}$, Selviana Napitupulu ${ }^{5}$ \\ 1,2,3,4,5 University of HKBP Nommensen Pematangsiantar \\ Email: dheaasaragih@gmail.com
}

\begin{abstract}
This research was conducted with the aim of channeling information about learning strategies that educators can use to provide speaking teaching to students majoring in tourism. The instrument to collected the data in this research is by doing a library research. Through library research, researchers carry out activities by finding materials related to this research. The data collection technique used in this research is library research. This is an activity to collect materials related to research originating from books, scientific journals, literatures and other publications, which are worthy as the sources for research that the researchers examined, by describing the data through some opinions of experts. Using qualitative approach in this research is expected to provide a comprehensive facts about strategies to improve English speaking skill for tourism students. The benefit of this research is to add insight to readers, especially for the educator, regarding the role of learning strategies to increase speaking skills in the tourism sector.
\end{abstract}

Keywords: Speaking Skill, Tourism, Student, Strategies, English.

\section{A. INTRODUCTION}

Tourism is an industry that plays a role in increasing country's revenue. By developing the tourism sector, the existence of a country can reach to all over the world and can bring international tourists. With this development, the broad job will be created for the public. One of the most popular industries by the world community is the tourism field. In every tourist spot in a country every year, many tourists will visit certain destinations, such as for vacation, for personal matters, and for education.

Since Tourism is one of the country's revenues, every country in the world begins to prepare a way to welcome the domestic and international visitors, which means adequate human skills and resources needed. To produce skilled human resources, a number of educational institutions have been organized throughout the world.

The skills needed in the Tourism context, of course is the direct communication skill. And as researchers know, language is the main media for someone to communicate with each other. Through this context, language is a significant media for tourism.

Like the data obtained by the United Nations World Tourism Organization (UNWTO) in 2016, the number of tourists visiting a country has always increased. In 1950 the number of tourists was 25 million, then in 1980 increased to 278 million, then in 2010, it increased rapidly to 674 million, and in 2015 increased to 1186 million. In this case, the use of the most widely used languages throughout the world is English, and it makes English as a global language, which is used by people (native and non-native) throughout the world.

An expert states that the parties in the tourism industry must have the ability to 
communicate effectively in English because English is the language that is most widely used by the entire world community to communicate when traveling abroad (Cohen, 2004). According to those statements, the researchers conclude that the ability to communicate or speaking ability is needed in the tourism sector. To become a tourist personnel who is capable of speaking, there are few strategies to improve this ability.

Tourism students must have good speaking skills, so that, in the future, they can apply it in the work fields. However, until now, there are still various problems faced by students in expressing their communication skills, such as the lack of pronunciation, lack of confidence, and lack of critical thinking. To overcome the problems mentioned, and to strengthen the foundation of students to improve their speaking skills, several strategies can be carried out, which can support the development of students' abilities. These strategies are expected to reduce the problems experienced by students and enable them in sharpening their skills.

Several studies related to students' perception about the importance of english speaking skill in tourism sector have been conducted before. Rao and abdullah (2007) did a research about the role of english language in the tourism industry. The result of the research shows that the human resource factor plays an eminent role in promoting the tourism spot in a country. Another Researcher, Simion (2012) did a research about the importance of teaching english in the field of tourism in universities.

From several of the studies above, the researchers can conlude that English and the ability to speak or the speaking ability of English play the most important role in the tourism sector.

\section{B. LITERATURE REVIEW}

\section{Speaking Skill}

Speaking is a functional oral skill in everyday human life. By speaking or by talking, we can obtain and convey information. But for Indonesian citizens, speaking English fluently is a tough challenge because Indonesian people don't use English as a language of everyday communication. Training and increasing English skills for students in speaking oral is one of the tasks of educators.

According to Ladouse (at the Nunan, 1991: 23), 'speaking is an activity to explain someone in a certain situation or activity to report something'. Whereas according to Tarigan (1990: 8) "Speaking is a way to communicate that influences our daily life". This means that speaking is a way of communicating that can affect someone's life.

Based on the explanation above, the researchers conclude that speaking is a way to state what we feel, which is then realized in the form of oral language processes between two or more speakers. Speaking is one of the skills in English that makes sound. The researchers can provide a statement that speaking is an activity to communicate and express opinions verbally. In speaking, the sentences spoken often contain implicit information. Thus, speaking is a skill that can show someone's ability to communicate. Speaking is one of the productive skills, which means in its development carried out after listening, which listening is one of receptive skills. Therefore, speaking is one oral activity in productive skills, which in fact more than just say opinions and thoughts through words.

Generally, there are four categories used in a conversation. The first category is 
communicative ability and content, which refers to the interlocutor's ability to express opinions and information. The second category is pronunciation and fluency, which refers to the interlocutor's ability to produce comprehensible language and other aspects such as stress patterns, amount of hesitation and accent. The third category is lexical accuracy and range which refers to the interlocutor's ability to accurately and appropriately use vocabulary in communication. The fourth category is grammatical accuracy and range which refers to the range and accuracy of the grammatical structures which the speaker and hearer use during the conversation.

\section{Tourism Students}

Tourism is a field that means activity to explore time away from residence, with the purpose of relaxation, pleasure, and recreation by utilizing tourism services, such as hotels, trips and cafes or restaurants.

Tourism students are the students who learn about tourist attractions in the surrounding area and outside their area. As tourism students, they will be asked to recognize a tourist area and be able to introduce it. They also must be able to understand the graph of increasing or decreasing the number of visitors.

\section{Relationship of English-Speaking Skill and Tourism Students}

In the tourism industry, speaking is one of the important skills to be considered. To get a good feedback from tourists, a tourism industry must be able to provide the best service that can be provided, one of which is the ability to communicate directly or through speaking skill. With good communication skills, a tourism industry will be able to attract more foreign tourists to visit.

Likewise with the tourism students who have interest in the field of tourism. They must have the ability to speak English well as an international language. This can add their value to a certain education. Tourism students not only use speaking skills to communicate everyday, but also for their needs based on the goals they want to achieve in the tourism field.

Speaking skill is closely related to student's tourism. In the sector of tourism, speaking is a very important component. It supports and makes a travel service run well. A tourism student must be able to speak correctly so that other people can understand easily the statements. One thing that tourism student's need to pay attention in speaking skills is pronunciation, fluency and tone when speaking. These ability will be the big components in student's tourism successness.

\section{METHOD}

The approach used in this research is a qualitative approach that is used to find out or describe the reality of the incident studied so that it makes it easy to get objective data. Sugiyono (2015:209) said that the qualitative research method is used by researchers in natural objects. According to Moleong (2009: P6), qualitative research is "research that intends to understand the phenomenon of what is experienced by research subjects such as behavior, perception, motivation, actions, etc., holistically, and by means of descriptions in the form of words and language, in a natural context that is naturally and by utilizing various natural methods". 
Based on the definitions above, it can conclude that qualitative research is a natural research and data produced in the form of descriptive. The data collection technique used in this study is library research. Library research is activity to collect materials related to research, from scientific journals, literatures, and writing products. The library research is carried out to obtain information that is theoretical so that researchers have a strong theoretical foundation as a scientific result. The data in this research are based on relevant books and journals.

The data analysis technique used in this research was an analysis of qualitative data, which in the form of opinions put forward by experts on strategies to increase speaking skills. These data are used as basis for strengthening researchers' arguments in analyzing strategies to increase speaking skill for tourism students.

\section{RESULT AND DISCUSSION}

Based on research conducted by researchers, some of the results of the library research that have been reviewed by researchers provide information related to strategies that can be used to increase student speaking skills, especially students who are involved in the tourism sector.

According to William and Burden (2003), teaching strategies applied by the educator are the factors of language learning success or failure. It means that it is important for the educator to determine the teaching strategy based on the situations of the students. In addition, Reiser and Dick (1996) stated that in the learning process, the educator can use various strategies to archive the goals and the objectives in the teaching and learning process. It means that the educator has responsibility to make sure that his/her students may speak in English by applying the appropriate teaching strategies to teach speaking.

Richards and Renandya (2005) also stated that the goal of language teaching is to provide communicative competence and classroom activities to the learners, so that the learners' can improve their speaking abilities. Teaching strategy is very important to teach language, especially in teaching English skill. In short, the teaching strategies are important to determine the success of teaching and learning process. These strategies are used to make the students interested in following the learning process, and to make students more focused and can pay their attention to the explanation by the educator when teach the students.

Anjaniputra (2013) stated that several strategies that used to teach speaking are cooperative activities, such as creative tasks, drilling, and role play. In addition, (Khamies, 2007) stated there are also several strategies that can be used to teach language by using media, such as poems, chants, stories, drama, games, and Total Physical Response (TPR) activities. These medias can be used to teach language and affect the learners and enhance their learning progress in learning the language.

Role play is a talking activity when student play a role, each student can become anybody. This will certainly develop their ideas and expand their imagination in using various appropriate expressions when practicing talking.

According to Richards, et al (2002:460): "Role play or also called playing roles in teaching English is teaching and learning activity in class, such as drama where students play the role of individuals differ in one situation and play a role like what happened in the situation. For example, practicing how to disclose complaints and apologies in a foreign 
language, students can play situations where customers in a store return the damaged items to the shopkeeper ".

In a public speaking class, role play can be very imaginative because students can be 'anyone' they want in a short time, such as being president, doctor, tour guide, news carriers and witnesses, pop singers, etc. This matter can attract attention and interest in tourism students because they certainly have a particular profession that is their ideals that they will play in real life. It can also be various roles can represent their desire to be someone they admire, just like many teenagers who like work as a tour guide. And they can manifest in a positive activity to develop creativity and improve their language skills.

Another strategy to teach speaking is by using drilling. According to Houston (2013) drilling is a way of standardizing pronunciation of a language item and developing fluidity (the ability to introduce language quickly and easily). It means that drilling is a good strategy, which can be used to teach pronunciation of English words for the students and can make them learn pronunciation easily. In addition, Harmer (2007) states, 'drilling is a mechanical ways in getting students to demonstrate and practice their ability to use specific language item in a controlled manner'.

The drill method is an exercise with the practice carried out repeatedly or continuously to get practical capabilities and dexterity about the knowledge learned. More than that, it is expected that the knowledge or abilities that have been studied are permanent, steady and can be used at any time by the concerned.

Another strategies that the educators can used is by using pictures, such as pictorial story. The pictorial story is a radiant image that contains stories or chronological order. This pictorial story can be used as media in teaching English especially for speaking skill.

According to Neuman (2010: 21), "media is often related with means of communication. the term media often refers of any device that brings information from the source of message to the destination". It means that media is often referred to as a communication tool. This term refers to a tool that carries information from the source of the message to the destination, namely the listener or recipient of the message.

In everyday life, television, radio, newspapers, magazines, leaflets, billboard, posters are called as media. All of these media are used to facilitate information transfer. In teaching and learning activities, the media is often used by educators to assist the process of student learning activities to be easier. With pictures, students can develop their ideas or stories based on images and express them with the style of their own language and choice.

All of the four strategies, namely role play, drilling, guessing games, and picture, based on the experts, show that they are appropriate to be used to improve students' speaking skill. And there is also another strategy that can be used to improve students' speaking skill, namely discussion group.

Discussion group according to Ernasari (2011) is a responsive scientific exposure where there is an exchange of opinions that are constructed with the problems of the appearance of ideas and opinions carried out by several people who are members of the group who are directed to obtain their problem solving and to seek the truth.

In addition, Dewa Sukardi (2008) stated that the discussion group is a association or meeting of two or more people with the aim of exchange of opinions and experiences, which usually have results in a decision based on the results of shared deliberation. By 
implementing this discussion group strategy, the tourism students can become more active as they will be divided into small groups. In those groups, they will discuss a topic that has become their concerns.

Discussion group is an activity to make conversation conducted by several people who are members of a group to exchange opinions to find answers to something that is being discussed. In this discussion group, students not only talk to solve a problem, they are also aroused to think more critically so that they are able to voice their opinions through speaking. By implementing the discussion group strategy, students tend to have a better mindset than students who work alone. Thus, the discussion group is a teaching teaching strategy that is good to apply, so that the students can improve their speaking ability using the right grammar.

Based on the few results of library research that the researchers did, researchers obtained several strategies that could be used to increase speaking skills for tourism students. Among them are role play, drilling, guessing games, using picture, and discussion group. The application of some of these strategies can be done by the educator to support the speaking skills of the tourism students, so that later they can apply the skill to adhere in work field. Based on the library research that researchers did, role play can help students learn actively and independently. Through this strategy, students can reveal identity in accordance with their role in the learning process. The students will be more convenient to express their vocabulary and will improve their speaking skills properly.

Then, for drilling strategy. After researchers conducted the research, drilling is also an appropriate strategy that the educator can apply to teach speaking. Drilling can provide some benefits to improve student speaking skills, such as increasing opportunities for students to learn new languages, and then they can start to find new vocabulary in their minds, and remember it for a long time.

Then, as researchers know that English is a language that has been widely used throughout the world. Therefore, English speaking skills must be owned by every student, especially for students in the tourism field. As a foreign language learned by students, educators can apply guessing games to improve student speaking skills. Through guessing games, learning situations will be more fun and not boring, because all students will become more active to express their opinions through the words. And through this, their speaking skills will slowly increase over the time. Other strategy that can be applied is by using picture. Through picture, students can express their opinions freely according to their minds. For example, the educator provides pictures of tourist destinations for students, then they will automatically reveal how the tourist destination orally. In certainty, it will improve student's speaking skill, especially for the students in the field tourism sector.

The last strategy in this research found by researchers, is to use the discussion group. Through discussion group, students can exchange their mind with others orally. And this will give them access to think more critically and help them to pronounce English vocabulary better, so that their speaking skills can increase. This strategy can be applied by the educator to improve student skills in the tourism sector. 


\section{E. CONCLUSION}

The researchers can conclude that speaking skill is a skill that is needed by tourism students. This is caused by the special advantage of speaking in influencing the students of the toursim field, which is to train them to be able to voice their opinions and provide instructions directly when working in the field of tourism. Therefore, there are several strategies that can be applied by educators to help students to be able in improving their speech skills. Through this research, researchers have described the details of the strategies that can be used by the educators to teach speaking to the tourism students.

\section{REFERENCES}

Anjaniputra, A. G. (2013). Teacher's Strategies in Teaching Speaking to Students at Secondary Level in Sumedang. Journal of English and Education, 1(2), 1-8.

Chastain, A. (1976). Theory to Practice. Chicago: University of Virginia.

Cohen. (2004). Contemporary Tourism: Diversity and Change. England: Emerald Group Publishing Limited.

Ernasari. (2011). The Effectiveness of Inquiry Models with Discussion Methods in Improving Learning Outcomes. A Thesis: UPI Bandung.

Harmer. (2007). How to Teach English. London: Longman.

Houston, H. (2013). Teaching Techniques-Drilling. Retrieved from: http://www.eslbase.com/tefl-a-z/drillin

Kelly, M. \& Stafford, K. (1993). Managing Small Group Discussion (Workshop Series No. 9). City Polytechnic of Hong Kong.

Moleong, L. J. (2009). Qualitative Research Method. Bandung: Remaja Rosdakarya.

Neuman, R. W. (2010). Theories of Media Evolution. The University of Michigan Press.

Ozer, O. (2005). Using Class Discussion to Meet Your Teaching Goals. Retrieved from Fall Newsletter.

Reiser, R. A., \& Dick, W. (1996). Second Edition of Instructional Planning: A Guide for Teacher. Boston: Allyn and Bacon.

Richards, Jack and Schmidt. (2002). Third edition of Longman Dictionary of Language Teaching and Applied Linguistics. UK: Pearson Education Ltd.

Richards, J., \& Renandya, W. (2005). Communicative Language Teaching Today. Singapore: SEAMEO Regional Language Center.

Simion, M. O. (2012). The importance of teaching English in the field of tourism in universities. Annals-Economy Series, 2, 152-154.

Sugiyono. (2015). Educational Research Method. Bandung: Alfabeta.

Sukardi, D. (2008). Introduction to The Implementation of a Counseling Program at School. Jakarta: Rineka Cipta

Tarigan, H. (2008). Speaking: As A Language Skill. Bandung: Angkasa.

William, M., \& Burden, R. L. (2003). Psychology for Language Teachers. Cambridge: Cambridge University Press. 